Jurnal Indonesia Sosial Teknologi: p-ISSN: 2723 - 6609

e-ISSN : 2745-5254

Vol. 2, No. 6 Juni 2021

\title{
ANALISIS KINERJA PEMERINTAH DESA DALAM PENGELOLAAN SAMPAH DI TPS GEDANGAN KABUPATEN SIDOARJO
}

\author{
Binti Azizatun, Febby Maulana Hakim Kubro, Fina Aura Regita, dan Nabilah \\ Dinda Permatasari
}

Program Studi Administrasi Publik, UPN Veteran Jawa Timur

Email: binti.azizatun.adneg@upnjatim.ac.id, febbymaulanahakim@gmail.com, nabilahdindapermatasari@gmail.com fina.aura26@gmail.com

\section{Abstract}

Sidoarjo Regency is one of the areas with the highest volume of waste in East Java after Surabaya. The potential for household waste production in Sidoarjo Regency reaches $4,517 \mathrm{m3}$ or around 2,400 tons per day and only 600 tons has been managed properly. The remaining 1,800 tons cannot be managed properly. The obstacles faced by the Government of Gedangan Village, Sidoarjo Regency in managing waste properly, of course, cause new problems for the surrounding community. As happened at one of the TPS in Gedangan District, Sidoarjo Regency. Several work programs that have not been implemented properly have resulted in the implementation of waste management at TPS Gedangan to date not going well. This study aims to answer what the village government has done in waste management at TPS Gedangan, Sidoarjo Regency. This research uses a descriptive research method with a qualitative approach. The results of this study indicate that in general the performance of the Village Government in waste management at TPS Gedangan Sidoarjo Regency is not optimal.

Keyword: public organization; public organization performance; productivity; waste management.

\section{Abstrak}

Kabupaten Sidoarjo merupakan salah satu daerah yang memiliki volume sampah tertinggi di Jawa Timur setelah kota Surabaya. Potensi produksi sampah rumah tangga di Kabupaten Sidoarjo mencapai $4.517 \mathrm{~m}^{3}$ atau sekitar 2.400 ton per hari dan hanya 600 ton yang berhasil dikelola dengan baik. Sebanyak 1.800 ton sisanya tidak mampu dikelola dengan baik. Kendala yang dihadapi oleh Pemerintah Desa Gedangan Kabupaten Sidoarjo dalam mengelola sampah dengan baik tentunya menimbulkan permasalahan baru bagi masyarakat sekitar. Seperti halnya yang terjadi di salah satu Tempat Penampungan Sementara di Kecamatan Gedangan Kabupaten Sidoarjo. Beberapa program kerja yang belum dilaksanakan dengan baik menyebabkan pelaksanaan pengelolaan sampah di TPS Gedangan hingga saat ini belum berjalan dengan baik. Penelitian ini bertujuan untuk menjawab kinerja apa saja yang telah dilakukan oleh Pemerintah Desa dalam pengelolaan sampah di TPS Gedangan Kabupaten Sidoarjo. Penelitian ini menggunakan metode penelitian kualitatif dengan penelitian bersifat deskriptif. Hasil penelitian ini mengindikasikan 
Binti Azizatun, Febby Maulana Hakim Kubro, Fina Aura Regita, dan Nabilah Dinda Permatasari

bahwa secara umum kinerja Pemerintah Desa dalam pengelolaan sampah di TPS Gedangan Kabupaten Sidoarjo belum cukup optimal.

Kata kunci: organisasi publik; kinerja organisasi public; produktivitas; pengelolaan sampah.

\section{Pendahuluan}

Sejalan dengan semakin meningkatnya aktivitas serta mobilitas masyarakat di perkotaan, permasalahan mengenai sampah semakin sulit ditangani oleh pemerintah terlebih di kota-kota metropolitan di Indonesia. Meskipun dampak yang ditimbulkan terkait permasalahan sampah ini telah nyata di depan mata, akan tetapi penanganan sampah seperti bukan menjadi prioritas utama pembangunan di Indonesia. Timbulnya permasalahan lain seperti banjir, pencemaran air, serta masalah kesehatan merupakan dampak nyata dari penanganan sampah yang kurang optimal. Menurut (Prabwati, 2018), permasalahan yang hampir dihadapi oleh banyak kota di seluruh dunia salah satunya adalah sampah. Seiring dengan bertambahnya aktivitas industri serta jumlah penduduk, membuat volume sampah terus bertambah setiap harinya.

Di pulau Jawa sendiri selaku pusat dari segala sektor ekonomi, sosial, dan politik di Indonesia, kemajuan industri dan teknologi masyarakat masih berbanding terbalik dengan pengelolaan sampah yang masih belum terselesaikan. Dalam Peraturan Menteri Pekerjaan Umum No.21/PRT/M/2006 tentang Kebijakan dan Strategi Nasional Pengembangan Sistem Pengelolaan Persampahan menyebutkan bahwa pengurangan sampah yang dimulai dari sumbernya merupakan hal yang harus diperhatikan dan mulai digalakkan. Selanjutnya dalam Undang-Undang Republik Indonesia Nomor 18 (2008) tentang Pengelolaan Sampah menjelaskan bahwa pengelolaan sampah di Indonesia yang berupa pengumpulan, pengangkutan dan pembuangan residu.

Salah satu wilayah yang menghasilkan volume sampah tertinggi di Indonesia yaitu Jawa Timur. Hal ini dikarenakan Jawa Timur merupakan wilayah yang besar dan luas, di sisi lain juga memiliki banyak kota dan kabupaten. Luasnya wilayah di Jawa Timur mendorong potensi banyaknya volume sampah yang dihasilkan tiap harinya baik dari industri maupun rumah tangga. Kota pertama penghasil volume sampah tertinggi di Jawa Timur adalah Kota Surabaya. Akan tetapi, permasalahan sampah di Kota Surabaya telah dapat dikelola dengan baik (Ardiansyah, 2016). Pengelolaan sampah secara optimal mampu mengantarkan Kota Surabaya meraih banyak penghargaan terkait upaya dalam pengelolaan sampah. Pada tahun 2019, Surabaya meraih tiga penghargaan dari Kementerian Lingkungan Hidup dan Kehutanan (KLHK) yaitu Adipura Kencana, Kinerja Pengurangan Sampah, dan Nirwasita Tantra.

Setelah kota Surabaya, daerah penghasil volume sampah tertinggi kedua di Jawa Timur adalah Kabupaten Sidoarjo. Berdasarkan data Dinas Catatan Sipil Kabupaten Sidoarjo pada tahun 2018, tercatat sebanyak 2.238.069 jiwa atau mengalami kenaikan 1,38\% dari tahun 2017 (BPS Sidoarjo, 2019). Potensi produksi sampah rumah tangga di Kabupaten Sidoarjo mencapai $4.517 \mathrm{~m}^{3}$ atau sekitar 2.400 ton per hari dan hanya 600 
ton yang berhasil dikelola dengan baik. Sebanyak 1.800 ton sisanya tidak mampu dikelola dengan baik. Undang-Undang Nomor 28 (2009) tentang Pajak Daerah dan Retribusi Daerah dan Peraturan Daerah Kabupaten Sidoarjo Nomor 6 (2012) tentang Pengelolaan Sampah dan Retribusi Pelayanan Persampahan/Kebersihan menunjukkan bahwa penambahan volume sampah yang terjadi berbanding lurus dengan bertambahnya jumlah penduduk. Artinya, jumlah volume sampah di Kabupaten Sidoarjo saat ini mengalami peningkatan dibandingkan periode sebelumnya (Tamyiz \& Prasetyo, 2018).

Pemerintah Daerah Kabupaten Sidoarjo membentuk Peraturan Daerah tentang pengelolaan sampah, yaitu Peraturan Daerah Kabupaten Sidoarjo Nomor 6 (2012) Tentang Pengelolaan Sampah. Hal ini menunjukan bahwa dalam pengelolaan sampah perlu melibatkan pemerintah daerah kabupaten/kota, Selain itu, pengelolaan sampah juga melibatkan peran serta pemerintah desa dalam rangka menuju pembangunan desa. Pemerintah daerah memfasilitasi pembentukan lembaga pengelola sampah di desa atau kelurahan, kecamatan, kawasan komersial, kawasan industri, fasilitas umum, fasilitas sosial, dan fasilitas lainnya, sesuai dengan kebutuhan.

Meskipun pemerintah Kabupaten Sidoarjo melalui Dinas Lingkungan Hidup dan Kebersihan telah mengembangkan inovasi pengolahan sampah dengan membangun infrastruktur dasar yaitu Tempat Penampungan Sementara (TPS), Tempat Pengolahan Sampah dengan prinsip reduce, reuse, dan recycle (TPS 3R), Stasiun Peralihan Antara (SPA), Tempat Pengolahan Sampah Terpadu (TPST) dan Tempat Pemrosesan Akhir (TPA) (Marlena et al., 2020). Pemilihan lokasi TPS sampah pada dasarnya harus ditetapkan berdasarkan pertimbangan pertimbangan khusus, supaya TPS sampah yang ditetapkan tidak mengganggu aktivitas penduduk maupun kondisi lingkungan sekitarnya (Hardiyanti \& Subowo, 2019).

Kinerja pengelolaan sampah dapat dipahami sebagai perbandingan antara hasil yang telah dicapai oleh organisasi dengan sasaran yang telah direncanakan sebelumnya dalam sistem pengelolaan sampah. Untuk menilai kinerja organisasi dalam pengelolaan sampah sangat erat kaitannya dengan kualitas pelayanan serta kepuasan yang didapatkan oleh masyarakat (Usman, 2017).

Pengelolaan sampah dapat didefinisikan sebagai usaha dalam mengatur dan mengelola sampah mulai pengumpulan, pemisahan, pemindahan, sampai pengelolaan dan pembuangan akhir (Dinas Cipta Karya, 1993). Menurut (Suryani, 2014) menyatakan bahwa tujuan dari sistem pengelolaan sampah pada dasarnya adalah menciptakan kota yang sehat, bersih, dan teratur. Untuk mencapai tujuan tersebut, sistem pengelolaan sampah memiliki aspek-aspek yang satu dengan lainnya saling mendukung, saling berinteraksi. Aspek-aspek tersebut adalah aspek teknis, kelembagaan, pembiayaan, hukum, dan partisipasi peran masyarakat.

Dari pemaparan latar belakang di atas, peneliti tertarik untuk mengkaji lebih dalam tentang Kinerja Pemerintah Desa dalam Pengelolaan Sampah di TPS Gedangan Kabupaten Sidoarjo karena Pemerintah Desa Gedangan merupakan instansi terkait yang 
Binti Azizatun, Febby Maulana Hakim Kubro, Fina Aura Regita, dan Nabilah Dinda Permatasari

memiliki kewenangan dan bertanggung jawab dalam mengelola permasalahan sampah di TPS Gedangan Kabupaten Sidoarjo sendiri.

\section{Metode Penelitian}

Penelitian ini menggunakan metode kualitatif dengan penelitian bersifat deskriptif. Menurut (Purnama, 2016) menjelaskan bahwa penelitian kualitatif adalah salah satu prosedur penelitian yang menghasilkan data deskriptif kualitatif berupa katakata tertulis atau lisan dari orang-orang dan perilaku yang diamati. Peneliti akan mencoba menggambarkan bagaimana kinerja dari Pemerintah Desa Gedangan dalam pengelolaan sampah di TPS Gedangan Kabupaten Sidoarjo. Lokasi penelitian di Kantor Pemerintah Desa Gedangan Kabupaten Sidoarjo, Dinas Lingkungan Hidup dan Kebersihan Kabupaten Sidoarjo dan di area TPS Gedangan Kabupaten Sidoarjo.

Teknik penentuan informan yang digunakan oleh peneliti pada penelitian kali ini adalah purposive sampling dan dikembangkan lagi menjadi snowball sampling. Teknik pengumpulan data oleh peneliti menggunakan metode observasi, in depth-interview, dokumentasi, serta studi literatur melalui penelitian terdahulu. Teknik analisis data yang digunakan oleh peneliti menggunakan reduksi data, penyajian data, penarikan kesimpulan, dan verifikasi. Teknik keabsahan data yang digunakan oleh peneliti dalam penelitian ini menggunakan teknik triangulasi dimana Susan Stanback (1988) dalam (Sugiyono, 2011) menyatakan bahwa tujuan triangulasi adalah meningkatkan pemahaman peneliti atas apa yang telah ditemukan.

\section{Hasil dan Pembahasan}

Kinerja Pemerintah Desa Gedangan Kabupaten Sidoarjo dalam pengelolaan sampah di TPS Gedangan secara umum belum dapat dikatakan belum optimal. Hal ini dapat dilihat melalui masih terdapat keterbatasan sarana prasarana di TPS Gedangan, kurangnya dana untuk perbaikan fasilitas, koordinasi yang belum baik, serta partisipasi dari masyarakat sekitar TPS yang masih jauh dari kata cukup. Pengelolaan sampah secara umum masih belum optimal. Hal ini dapat dilihat dari keterbatasannya baik dari kurangnya fasilitas dan dana, sistem pengelolaan sampah yang belum optimal, serta kurangnya partisipasi dari masyarakat. Dalam menilai kinerja Pemerintah Desa dalam Pengelolaan sampah di TPS Gedangan Kabupaten Sidoarjo ini, diperlukan aspek-aspek yang dapat digunakan sebagai cara untuk mengukur kinerja organisasi tersebut antara lain

\section{A. Produktivitas}

Berdasarkan hasil penelitian yang diperoleh dari wawancara dengan Kepala Desa Gedangan, dapat disimpulkan bahwa kinerja Pemerintah Desa Gedangan dalam pengelolaan sampah di TPS Gedangan belum maksimal dikarenakan kendala yang terjadi dalam beberapa program atau kegiatan yang telah direncanakan. Salah satu program yang dicanangkan oleh Pemerintah Desa Gedangan terkait pengelolaan sampah adalah Bank Sampah. Program ini bekerjasama dengan kelompok PKK di Desa Gedangan yang bertugas untuk mengolah sampah yang telah dipilih 
sebelumnya seperti sampah plastik, sampah organik, atau sampah kardus. Dari hasil wawancara, program ini belum berjalan dengan baik karena kendala minimnya lahan TPS Gedangan untuk proses pengolahan sampah. Pemerintah Desa Gedangan telah berupaya mengajukan bantuan alat untuk pengolahan sampah ke Dinas Lingkungan Hidup dan Kebersihan Kabupaten Sidoarjo sejak tahun 2019. Akan tetapi, hingga penelitian ini berlangsung bantuan alat yang diajukan belum dipenuhi oleh DLHK Kabupaten Sidoarjo.

Kurangnya sarana dan prasarana serta fasilitas yang memadai menjadi kendala utama bagi Pemerintah Desa Gedangan dalam menjalankan programprogram terkait pengelolaan sampah di TPS Gedangan Kabupaten Sidoarjo. Rencana program terkait pembangunan dan perbaikan TPS Gedangan yang direncanakan hingga saat ini. Lokasi TPS Gedangan yang sempit dan tidak memiliki tempat terbuka yang luas serta keterbatasan dana menjadi faktor penghambat salah satu program Pemerintah Desa berupa pengadaan incenerator atau mesin pengolah sampah. Permasalahan lain yang juga menjadi penghambat pengelolaan sampah di TPS Gedangan ini juga berasal dari kurangnya jumlah personil Pemerintah Desa Gedangan. Jumlah personil dalam pengelolaan sampah yang hanya berjumlah 10 orang membuat pengelolaan sampah menjadi tidak maksimal. Dalam mengatasi kurangnya jumlah personil, Pemerintah Desa Gedangan menginisiasi program pembentukan Satgas Lingkungan di Desa Gedangan untuk turut serta membantu menangani pengelolaan sampah di wilayah mereka.

Program seperti penyuluhan atau jaring aspirasi kepada masyarakat sampai saat ini belum terlaksana dengan optimal. Pembinaan kepada masyarakat pun seperti 3R (reuse, reduce, recycle) hingga saat ini belum berjalan dengan baik. di sisi lain, meskipun telah terlaksana penyuluhan dan pembinaan terhadap masyarakat terkait 3R, fasilitas dan sarana prasarana yang belum memadai juga nantinya akan menjadi penghambat program pembinaan tersebut.

\section{B. Responsivitas}

Dalam pembahasan responsivitas ini, kemampuan Pemerintah Desa terkait dengan pemenuhan kebutuhan masyarakat sekitar TPS Gedangan belum dapat dikatakan berjalan dengan baik. Terdapat banyak kendala yang membuat responsivitas Pemerintah Desa Gedangan dalam pengelolaan sampah di TPS Gedangan Kabupaten Sidoarjo belum berjalan dengan efektif. Salah satunya adalah belum adanya kegiatan atau program jaring aspirasi serta pengaduan terkait pengelolaan sampah. Masyarakat hanya memiliki akses bertemu langsung atau menyampaikan keluhan terlebih dahulu melalui telepon. Sikap Pemerintah Desa Gedangan dalam menanggapi keluhan masyarakat adalah dengan melakukan upaya menyelesaikan masalah yang diadukan ke mereka. Beberapa bentuk sikap Pemerintah Desa Gedangan dalam menjawab keluhan masyarakat seperti pengadaan gerobak sampah, pengajuan perbaikan TPS Gedangan, serta pengajuan incinerator untuk mengolah sampah. 
Binti Azizatun, Febby Maulana Hakim Kubro, Fina Aura Regita, dan Nabilah Dinda Permatasari

Respon yang diberikan Pemerintah Desa terhadap keluhan-keluhan masyarakat sekitar terkait pengelolaan sampah di TPS Gedangan dinilai belum optimal. Selain itu, kesadaran masyarakat pun dinilai juga masih minim yang mana segala urusan terkait problem sampah dilimpahkan hanya kepada Pemerintah Desa selaku instansi yang bertanggung jawab mengelola sampah di TPS Gedangan. Skala prioritas yang ditetapkan telah berjalan dengan baik dan masih dalam proses pengerjaan yaitu perencanaan pengadaan incinerator yang akan digunakan untuk mengatasi permasalahan volume sampah. Pemerintah Desa Gedangan juga tetap mengupayakan berjalannya pengelolaan sampah dengan optimal salah satunya dengan menggandeng lembaga masyarakat (PKK) yang khusus mengelola sampah atau bahkan mendaur ulang sampah tersebut.

\section{Akuntabilitas}

Akuntabilitas Pemerintah Desa Gedangan adalah berupaya meluaskan daerah pengelolaan dan pengolahan sampah, melakukan pemilahan sampah, menginisiasi pembentukan bank sampah, serta pengajuan pengadaan incinerator guna mengolah sampah di wilayah Gedangan. Sejauh ini, Pemerintah Desa telah berupaya untuk mewujudkan target yang telah mereka rencanakan sebelumnya terkait pengelolaan sampah di wilayah mereka. Akan tetapi, terdapat banyak kendala dalam mewujudkan rencana-rencana yang telah mereka tetapkan. Kurangnya sumber daya, dana, serta partisipasi masyarakat membuat program yang direncanakan sebelumnya tidak dapat berjalan sesuai target. Upaya lain yang dilakukan Pemerintah Desa Gedangan yaitu pengadaan gerobak sampah untuk memudahkan proses pengumpulan sampah dari tiap rumah. Meskipun banyak target yang belum tercapai, akan tetapi Pemerintah Desa Gedangan tetap berupaya melaksanakan tanggung jawab pengelolaan sampah di TPS Gedangan sampai saat ini.

Persoalan koordinasi dan transparansi antara Pemerintah Desa Gedangan dengan Dinas Lingkungan Hidup dan Kebersihan Kabupaten Sidoarjo merupakan salah satu kendala yang membuat kurang optimalnya pengelolaan sampah di TPS Gedangan. Selain itu, berdasarkan data yang diperoleh dari DLHK Kabupaten Sidoarjo, tingkat ketaatan Desa Gedangan terkait retribusi pengelolaan sampah masih belum memenuhi standar. Seringkali retribusi tidak dibayarkan dengan sesuai sehingga pengiriman truk pengangkut sampah ke TPS Gedangan tidak teratur. Dampaknya adalah seperti yang terjadi pada periode sebelum-sebelumnya, sampah menumpuk dan melebihi batas volume wajar sehingga meluber ke jalan raya.

1. Faktor-Faktor yang mempengaruhi Kinerja Pemerintah Desa dalam Pengelolaan Sampah di TPS Gedangan Kabupaten Sidoarjo

\section{a. Sumber Daya}

Ketersediaan sumber daya memiliki beberapa elemen di dalamnya seperti dana, pegawai, serta fasilitas sangat berpengaruh terhadap kinerja suatu organisasi. dalam pelaksanaannya, Pemerintah Desa Gedangan mengalami kendala dalam ketiga elemen sumber daya yang dimiliki. Dana yang belum 
mencukupi menyebabkan proses pengelolaan sampah di TPS Gedangan menjadi terhambat. masih minimnya sarana dan prasarana dapat dilihat dari kondisi yang ada di TPS tersebut, secara keseluruhan, dana yang dimiliki masih belum menunjang berjalannya pengelolaan sampah dengan baik di TPS Gedangan.

Sumber daya manusia berupa staff/pegawai di Pemerintah Desa Gedangan secara kuantitas belum cukup. Hal ini menyebabkan tidak mampunya Pemerintah Desa menjangkau aspirasi dari masyarakat sekitar secara menyeluruh terkait persoalan pengelolaan sampah di sekitar TPS Gedangan. Secara kualitas, staff/pegawai telah memiliki wawasan yang mumpuni terkait pengelolaan sampah di tempat tugas mereka. Fasilitas yang dimiliki oleh Pemerintah Desa Gedangan masih kurang mencukupi untuk melaksanakan pengelolaan sampah secara efektif di TPS Gedangan Kabupaten Sidoarjo. Hal ini dapat dilihat dari ketersediaan teknologi pengolahan yang masih minim atau bahkan tidak ada seperti alat penghancur sampah yang bertujuan memudahkan pengangkutan ke TPA pusat.

\section{b. Struktur Organisasi}

Struktur organisasi mencoba menggambarkan bagaimana pembagian kegiatan pekerjaan antara pegawai satu dengan pegawai lainnya serta hubungan aktivitas dan pembagian fungsi antar pegawai Salah satu indikator struktur organisasi yang baik adalah dengan menjelaskan hubungan antar siapa yang melapor dan siapa yang dilapor. Struktur organisasi sendiri mempunyai tiga komponen yang menjadi dasar, antara lain formalisasi. Sentralisasi, dan kompleksitas. Struktur organisasi di Pemerintah Desa Gedangan sangat formalis, hal ini ditunjukkan dengan pembagian tugas dan wewenang. Aturan dan prosedur yang harus dilaksanakan oleh pegawai pun telah ditetapkan secara spesifik Akan tetapi, kendala keterbatasan jumlah pegawai yang hanya 10 orang membuat pengelolaan sampah di TPS Gedangan Kabupaten Sidoarjo belum maksimal. Pemerintah Desa Gedangan juga memiliki struktur organisasi yang sentralistis dapat dilihat dari program-program, tugas, atau pekerjaan yang dilakukan setiap pegawai adalah perintah yang telah ditetapkan oleh kepala desa. Selanjutnya, kompleksitas menunjukkan bahwa tugas yang diterima oleh personil di Pemerintah Desa Gedangan cukup kompleks karena dengan 10 personil tidak hanya mengerjakan tugas terkait pengelolaan sampah tetapi juga tugas administratif lainnya.

\section{c. Partisipasi Masyarakat}

Menurut hasil wawancara dengan pegawai di kantor Pemerintah Desa Gedangan serta observasi dari daerah sekitar TPS Gedangan, keterlibatan masyarakat secara aktif dalam pengelolaan sampah di TPS Gedangan masih belum tercapai. Bahkan kesadaran masyarakat sekitar dalam pengelolaan sampah masih rendah seperti membuang sampah di sungai atau bukan di 
Binti Azizatun, Febby Maulana Hakim Kubro, Fina Aura Regita, dan Nabilah Dinda Permatasari

wadah tempat sampah. Hal ini juga disebabkan karena kurangnya jaring aspirasi yang dilakukan oleh Pemerintah Desa atau penyuluhan kepada masyarakat yang belum tepat sasaran. Masyarakat belum bisa bertanggung jawab dan bekerjasama dengan baik. Terkadang, masyarakat yang tidak berasal dari daerah Desa Gedangan turut membuang sampah secara ilegal di TPS Gedangan. Kesadaran serta partisipasi aktif dari masyarakat yang masih rendah hingga saat penelitian berlangsung turut andil dalam menghambat terciptanya pengelolaan sampah yang lebih baik di TPS Gedangan Kabupaten Sidoarjo.

\section{Kesimpulan}

Berdasarkan hasil penelitian yang telah dijelaskan dan dipaparkan sebelumnya, dapat disimpulkan bahwa kinerja Pemerintah Desa Gedangan dalam pengelolaan sampah di TPS Gedangan Kabupaten Sidoarjo secara umum belum terlaksana dengan optimal. Pelaksanaan yang belum optimal dari kinerja Pemerintah Desa Gedangan terkait pengelolaan sampah dapat dilihat dari tiga dimensi yang digunakan untuk mengukur kinerja organisasi yaitu produktivitas, responsivitas, dan akuntabilitas. 


\section{Bibliografi}

Ardiansyah, D. (2016). Kinerja Dinas Kebersihan dan Pertamanan Kabupaten Sidoarjo dalam Pengelolaan Sampah. Jurnal Kebijakan Dan Manajemen Publik Universitas Airlangga, 4(2), 188-198.

BPS Sidoarjo. (2019). Badan Pusat Statistik Kabupaten Sidoarjo dalam Angka 2019.

Dinas Cipta Karya. (1993). Penyusunan Pedoman Teknik Operasi dan Pemeliharaan Pembangunan Prasarana Perkotaan (Komponen Persampahan). Jakarta.

Hardiyanti \& Subowo. (2019). Analisis Kinerja Organisasi Dinas Lingkungan Hidup Kabupaten Demak Dalam Pengelolaan Sampah. 68-70. $\underline{10.14710 / j p p m r . v 8 i 2.23545}$

Marlena, M., Adi, T. J. W., \& Warmadewanthi, I. D. A. A. (2020). Evaluasi Kinerja Aset Tempat Pengolahan Sampah Terpadu (TPST) di Kabupaten Sidoarjo. Jurnal Manajemen Aset Infrastruktur \& Fasilitas, 4(3), 211-218. https://doi.org/10.12962/j26151847.v4i3.7101

Peraturan Menteri Pekerjaan Umum No.21/PRT/M/2006 tentang Kebijakan dan Strategi Nasional Pengembangan Sistem Pengelolaan Persampahan.

Perda Kabupaten Sidoarjo Nomor 6. (2012). Peraturan Daerah Kabupaten Sidoarjo Nomor 6 Tahun 2012. Pengelolaan Sampah Dan Retribusi Pelayanan Persampahan/Kebersihan. 1965, 1-28.

Prabwati, I. (2018). Evaluasi Program Zero Waste Indra Propatria D. W Abstrak.

Purnama, Y. (2016). Kajian Nilai Budaya Dalam Carita Pantun Sawung Galing. Patanjala: Jurnal Penelitian Sejarah Dan Budaya, 8(2), 187. https://doi.org/10.30959/patanjala.v8i2.72

Sugiyono. (2011). Metode Penelitian Pendidikan (Pendekatan Kuantitatif, Kualitatif, dan $R \& D)$. Bandung: Alfabeta.

Suryani, A. S. (2014). Peran Bank Sampah Dalam Efektivitas Pengelolaan Sampah (Studi Kasus Bank Sampah Malang). Jurnal Aspirasi, 5(1), 71-84. https://doi.org/10.46807/aspirasi.v5i1.447

Tamyiz \& Prasetyo. (2018). Pendistribusian Sampah Di Kabupaten Sidoarjo Menggunakan Aplikasi Simulasi. Journal of Research and Technology, 4(2), 113122. 
Binti Azizatun, Febby Maulana Hakim Kubro, Fina Aura Regita, dan Nabilah Dinda Permatasari

Undang-Undang Republik Indonesia Nomor 18 Tahun 2008 Tentang Pengelolaan Sampah.

Undang-Undang Republik Indonesia Nomor 28 Tahun 2009 tentang Pajak Daerah dan Retribusi Daerah.

Usman, L. (2017). Analisa Kinerja Pengelolaan Sampah Di Kota Gorontalo ( Studi Kasus Kecamatan Kota Selatan ). 5(1), 47-54. https://doi.org/10.37971/radial.v5i1.142 